JURNAL MANAJEMEN KESEHATAN Yayasan RS Dr. Soetomo, Vol. 3 No. 1, April 2017 : 15- 30

\title{
STUDI HUBUNGAN ANTARA MUTU PELAYANAN KESEHATAN DENGAN KEPUASAN PASIEN DI UNIT PELAYANAN RAWAT INAP RUMAH SAKIT UMUM DAERAH BHAKTI DHARMA HUSADA KOTA SURABAYA
}

\author{
Eka Nurcahyanti, Happy Setiawan* \\ *Prodi S1Administrasi Rumah Sakit, STIKES Yayasan Rumah Sakit Dr. Soetomo \\ Jl. Karangmenjangan No. 12 Surabaya \\ Email : ekanurcahyanti3@gmail.com
}

\begin{abstract}
ABSTRAK
Mutu pelayanan merupakan evaluasi yang difokuskan pada pengaruh persepsi konsumen terhadap dimensi-dimensi spesifik dari pelayanan.Kepuasan pasien merupakan indikator yang penting untuk pengukuran mutupelayanan pasien, karena ketidakpuasan petunjuk peluang untuk melakukan perbaikan. Saat ini, jumlah komplain pengguna layanan di Rumah Sakit Umum Daerah Bhakti Dharma Husada cukup tinggi. Penelitian ini bertujuan untuk mengetahui hubungan antara mutu pelayanan kesehatan dan kepuasan pasien rawat inap di Rumah Sakit Umum Daerah Bhakti Dharma Husada. Sebuah studi korelasional yang dilakukan dari bulan April sampai Juli, 2016. Kuesioner mutu pelayanan kesehatan dikembangkan dari "Brady dan Cornin" menggunakan tiga dimensi mutu pelayanan, mutu interaksi, mutu lingkungan fisik, dan mutu hasil. Kuesioner kepuasan pasien menggunakan Client Satisfication Quistionnare 8 (CSQ 8). Responden dalam penelitian ini adalah 155 pasien rawat inap di rumah sakit Umum Daerah Bhakti Dharma Husada. Hasil penelitian ini menunjukkan bahwa ada hubungan yang signifikan antara mutu pelayanan kesehatan dan kepuasan pasien ( $\mathrm{p}=0.000, \mathrm{n}=155, \mathrm{p}$ hitung $>0,05)$. Hasil korelasi menunjukkan bahwa semakin tinggi mutupelayanan maka kepuasan pasien tinggi.
\end{abstract}

Kata Kunci: Mutu Pelayanan Kesehatan, Kepuasan Pasien Rawat Inap, Studi Kolerasional.

\section{ABSTRACT}

Quality of service is focused on the evaluation of the influence consumer perceptions of specific dimensions of service. Patient satisfaction is a valid indicator for measurement of service quality. Patients' judgment is importantbecause dissatisfaction hint the opportunities for improvement.Currently, high complain service users in the Regional Public Hospitals Bhakti Dharma Husada. This study aims to determine the relationship between service quality dan satisfaction of inpatients in the Regional Public Hospitals Bahkti Dharma Husada.A correlational study was design was conducted from April to July, 2016. Questionnaire quality health care was developed based on modified "Brady and Cornin" using theree service quality dimensions, quality interaction, quality pyhsical environment, and quality outcome. Questionnare patient satisfication using the Client Satisfication Quistionnare 8 (CSQ 8).The respondent for this study was 155 inpatients in Regional Public hospital Bahkti Dharma Husada. The findings indicated that there significant relationship between the quality health services and patient satisfication $(p=0.000, n=155, p>0.05)$. Results of the correlation indicate that the higher the service quality is associated with high patient satisfaction.

Keywords : Service Health Quality, Inpatient Satisfication, Correlational Study. 


\section{PENDAHULUAN}

Rumah sakit adalah institusi pelayanan kesehatan bagi masyarakat dengan karakteristik tersendiri yang dipengaruhi oleh perkembangan ilmu pengetahuan kesehatan, kemajuan teknologi, dan kehidupan sosial ekonomi masyarakat yang harus tetap mampu meningkatkan pelayanan yang lebih bermutu. Tujuan penyelenggaraan rumah sakit yaitu meningkatkan mutu pelayanan kesehatan serta memberikan kepastian hukum kepada pasien (Undang-undang Republik Indonesia Nomor 44 tahun 2009 tentang Rumah Sakit).

Mutu pelayanan kesehatan merupakan gambaran total sifat dari suatu jasa pelayanan kesehatan yang berhubungan dengan kemampuan untuk memberikan kebutuhan kepuasan pasien (Kotler, 2005). Menurut Gerson (2004), kepuasan pasien adalah persepsi pasien bahwa harapannya telah terpenuhi.

Menurut Budi (2012) mutu pelayanan bisa diukur dengan beberapa dimensi, dengan dimensi ini dapat menganalisis suatu pelayanan itu bermutu atau tidak. Brady dan Cornin (2001) mengembangkan konsep dimensi mutu pelayanan kesehatan dari Parasuraman (1985), dikembangkan menjadi 3 dimensi, meliputi; mutu interaksi (intreraction quality), mutu lingkungan fisik (physical environment quality), dan mutu hasil (outcome quality).

Survey kepuasan pasien di rumah sakit menjadi penting dan perlu dilakukan bersama dengan pengukuran dimensi mutu pelayanan kesehatan (Pohan, 2006). Perspektif penilaian kepuasan pelayanan meliputi; prespektif pemenuhan kebutuhan dan harapan pasien, serta perspektif penilaian pelayanan yang sudah diterima (Matsubaaret al, 2013).

Pernyataan diatas mendukung peneliti untuk berpendapat bahwa memilih penelitian di RSUD BDH. Berdasarkan survey awal yang peneliti lakukan pada RSUD BDH, rumah sakit ini merupakan rumah sakit tipe $\mathrm{C}$ milik Pemerintah Kota Surabaya. Dari survey awal ini didapatkan data-data awal yang mendukung dengan penelitian ini. jumlah komplain mengalami penurunan 12 komplain dari tahun 2014 yang berjumlah 207 komplain, sedangkan pada tahun 2015 menjadi 195 komplain. Komplain pada bagian umum dan bidang pelayanan medik mengalami kenaikan 13\% dan $24 \%$. Komplain tersebut masih tergolong tinggi, dimana hanya mengalami penurunan 12 komplain.

Survey kepuasan pasien yang tergambar pada tabel diatas, pada tahun 2014 yaitu $87 \%$ akan tetapi pada tahun 2015 menjadi 80\%, hal ini mengalami penurunan 7\%. Hasil survey 
kepuasan di tahun 2016 belum dilakukan dan pada survey mutu pelayanan kesehatan berdasarkan presepsi pasien di RSUD BDH belum pernah dilakukan survey. Padahal hasil kajian mutu dan kepuasan pasien merupakan salah satu elemen penting akreditasi rumah sakit (Standart Akreditasi Rumah Sakit, 2012). Penelitian ini, peneliti mengambil survey di unit pelayanan rawat inap. Karena unit pelayanan rawat inap merupakan tempat atau unit dimana terjadi interkasi yang mutual dan lama antara pasien, tenaga kesehatan dan keluarga

\section{METODE PENELITIAN}

Penelitian ini menggunakan pendekatan kuantitatif. Desain penelitian ini bersifat kolerasional dimana bertujuan untuk mengetahui hubungan antara mutu pelayanan kesehatan berdasarkan presepsi pasien dengan kepuasan pasien di unit pelayanan rawat inap RSUD BDH. Penelitian ini dilakukan pada bulan April sampai dengan Juni 2016, di unit pelayanan rawat inap Rumah Sakit Umum Daerah Bhakti Dharma Husada Kota Surabaya.

Populasi pada penelitian ini adalah ratarata jumlah pasien rawat inap pada ruangan representatif dalam satu bulan yaitu 360 pasien. Rata-rata jumlah pasien tersebut di dapatkan dari ruangan representatif yang dapat diteliti yaitu berjumlah 7 ruangan dari 16 ruangan yan ada di RSUD BDH. Dengan menggunakan tabel Nomogram Harry King bila populasinya 360, kesalahan yang dikehendaki peneliti yaitu adalah 10\%, maka jumlah sampelnya 155 pasien.Instrumen penelitian yang digunakan dalam penelitian ini menggunakan angket (questionnaire).

Skala item pertanyaan yang digunakanpadakuesioner mutu pelayanan kesehatan yaitu adopsi skala item pertanyaan Health Care Service Quality (HCSQ Scale) oleh Hardeep Chahal and Neetu Kumari (2010). Serta akan dilakukan konsultasi kepada seorang ahli mutu pelayanan kesehatan yang sudah berpengalaman dalam mutu pelayanan kesehatan di rumah sakit dan terdapat 22 butir pertanyaan. Kuesioner yang digunakan untuk mengukur kepuasan menggunkan kuesioner Client Statisfication Quistonare 8 (CSQ8) oleh Attkison (1983). Terdapat 7 butir pertanyaan tertutup.

Instrumen penelitian mutu pelayanan kesehatan dan kepuasan sebelum dibagikan kepada pasien dilakukan uji validitas isi (content validity) dan validitas konstruk (construct validity). Validitas isi kuesioner ditentukan oleh sejauh mana isi kuesioner tersebut mewakili semua aspek yang dianggap sebagai aspek kerangka konsep. 
STUDI HUBUNGAN ANTARA MUTU PELAYANAN ....(Eka Nurcahyanti)

Analisis data penelitian ini

1.1.

menggunakan bantuan dari SPSS versi 20 .

1.a.

Teknik analisis yang digunakan peneliti adalah

2.

uji kolerasi dengan rumus dari Karl Person.

Person Correlation adalah untuk mengetahui hubungan antara variabel $\mathrm{X}$ dan $\mathrm{Y}$ (Boedijoewono, 2001). Uji kolerasi untuk membuktikan bahwa ada hubungan antara variabel X (mutu pelayanan kesehatan) dengan variabel Y (kepuasan pasien). Untuk mengetahui signifikan atau tidak, menurut Karl Person dikatakan signifikan jika perolehan $\mathrm{p}$ hitung $=0.000<0.05$ dan tidak signifikan jika perolehan $\mathrm{p}$ hitung $=0.000>0.05$.

Penentuan nilai untuk mengetahui mutu pelayanan kesehatan dan kepuasan pasien menggunakan rumus menurut Arikunto (2010), sebagai berikut:

$$
\text { Nilai }=
$$

Pengklasifikasian nilai mutu pelayanan kesehatan dengan kepuasan pasien menggunakan pendapat Arikunto (2010), dimana dikategorikan sebagai berikut:

Mutu Pelayanan Kesehatan

1.1.1.a.1.a. $<40$ Tidak Baik

1.1.1.a.1.b.41-55 Kurang Baik

1.1.1.a.1.c. 56-75 Baik

1.1.1.a.1.d.76-100 Sangat Baik
2. Kepuasan pasien

a. $<40$ Tidak Puas

b. 41-55 Kurang Puas

c. 56-75 Puas

d. 476-100 Sangat Puas

Peneliti memungkin mengkaji lebih dalam antara variabel-raviabel $\mathrm{X}$ dan $\mathrm{Y}$ dengan menggunakan analisis canonical. Analisis canonical sebagai suatu teknik statistika peubah ganda (Multivariat) yang menyelidiki keeratan hubungan antara dua kelompok variabel. Satu variabel diidentifikasikan sebagai gugus variabel penduga (independent variabel) penelitian ini yaitu dimensi mutu pelayanan kesehatan yang terdiri dari; X1 dimensi mutu interaksi (interaction quality),X2 dimensi mutu lingkungan fisik (physical environment quality), X3 dimensi mutu hasil (outcome quality), dan perspektif kepuasan yang terdiri dari; Y1 (perspektif pemenuhan kebutuhan dan harapan pasien), dan Y2 (perspektif penilaian pelayanan yang sudah diterima). Sedangkan satu variabel lainnya diperlakukan sebagai gugus variabel respon (dependent variabel) yaitu Mutu pelayanan kesehatan $(\mathrm{X})$ dan kepuasan pasien $(\mathrm{Y})$. Analisis ini dapat mengukur tingkat keeratan hubungan antara satu kumpulan 
pengubah dependent dengan satu kumpulan

pengubah independent.

\section{HASIL DAN PEMBAHASAN}

\section{Hasil}

\section{Karakteristik Responden}

Tabel 1.1

Karakteristik Responden

\begin{tabular}{|c|c|c|}
\hline Karakteristik Responden & $\begin{array}{c}\text { Jumlah } \\
\text { Responden }\end{array}$ & $\%$ \\
\hline Jenis Kelamin & 62 & $40 \%$ \\
\hline Pria & 93 & $60 \%$ \\
\hline \multicolumn{3}{|l|}{ Wanita } \\
\hline \multicolumn{3}{|l|}{ Umur } \\
\hline Remaja Awal (12-16 th) & 7 & $4 \%$ \\
\hline Remaja Akhir (17-24 Tth) & 23 & $15 \%$ \\
\hline Dewasa (25-64 th) & 93 & $60 \%$ \\
\hline Manula (>65 th) & 32 & $21 \%$ \\
\hline \multicolumn{3}{|l|}{ Pendidikan Terakhir } \\
\hline \multicolumn{3}{|l|}{ Tidak Sekolah } \\
\hline SD & 8 & $5 \%$ \\
\hline SMP & 36 & $23 \%$ \\
\hline SMA & 35 & $23 \%$ \\
\hline Diploma & 51 & $33 \%$ \\
\hline Sarjana & 14 & $9 \%$ \\
\hline Pasca Sarjana & 11 & $7 \%$ \\
\hline \multicolumn{3}{|l|}{ Asuransi Kesehatan Sosial } \\
\hline Jaminan Kesehatan Nasional (JKN) & 124 & $80 \%$ \\
\hline Umum & 29 & $19 \%$ \\
\hline Asuransi Lain & 2 & $1 \%$ \\
\hline \multicolumn{3}{|l|}{ Pekerjaan } \\
\hline \multicolumn{3}{|l|}{ Tidak Bekerja/Ibu Rumah Tangga (IRT) } \\
\hline Swasta & 71 & $46 \%$ \\
\hline Wirausaha & 9 & $6 \%$ \\
\hline Tani & 1 & $1 \%$ \\
\hline Pelajar/Mahasiswa & 18 & $12 \%$ \\
\hline Buruh/Pembantu & 1 & $1 \%$ \\
\hline PNS/ABRI/POLRI/BMUN & 6 & $4 \%$ \\
\hline Total Responden & 155 & $100 \%$ \\
\hline
\end{tabular}


Sampel dalam penelitian ini berjumlah 155 responden. Responden dengan Jenis kelamin wanita 93 responden (60\%) paling banyak dibandingkan pria 62 responden (40\%). Karakteristik responden usia dewasa terdiri dari 93 responden (60\%) paling banyak dibandingkan usia remaja awal paling sedikit yaitu 7 responden (4\%). hasil analisis paling banyak responden dengan pendidikan terakhir SMA yaitu 51 responden (33\%) dibandingkan

\section{Mutu Pelayanan Kesehatan}

tidak sekolah paling sedikit yaitu 8 responden $(5 \%)$.

Pasien JKN paling banyak yaitu 124 responden $(80 \%)$ dibandingkan asuransi lain paling sedikit 2 responden (1\%).Pekerjaan Tidak Bekerja/Ibu Rumah Tangga paling banyak yaitu, 71 responden (46\%) dibandingkan jenis pekerjaaan tani dan buruh/pembantu paling sedikit yaitu 1 responden $(1 \%)$.

Tabel 1.2

Mutu Pelayanan Kesehatan

\begin{tabular}{|c|c|c|c|c|c|}
\hline & \multicolumn{4}{|c|}{ Kategori Nilai } & \multirow{2}{*}{ Nilai Mean } \\
\hline & $\mathbf{B}$ & $\%$ & SB & $\%$ & \\
\hline Mutu Pelayanan Kesehatan & 128 & $83 \%$ & 27 & $17 \%$ & 77 \\
\hline \multicolumn{6}{|c|}{ Dimensi Mutu Interkasi } \\
\hline Mutu Interaksi (Interaction Quality) & 132 & $85 \%$ & 23 & $15 \%$ & 77 \\
\hline 1. Aspek Sikap Dan Perilaku Perawat & 135 & $87 \%$ & 19 & $17 \%$ & 78 \\
\hline 2. Aspek Dukungan Staf & 139 & $90 \%$ & 15 & $10 \%$ & 77 \\
\hline 3. Aspek Perilaku Dokter & 136 & $88 \%$ & 18 & $12 \%$ & 77 \\
\hline 4. Aspek Keahlian & 132 & $85 \%$ & 23 & $15 \%$ & 78 \\
\hline $\begin{array}{l}\text { Mutu Lingkungan Fisik (Physical } \\
\text { Environment Quality) }\end{array}$ & 136 & $88 \%$ & 19 & $12 \%$ & 75 \\
\hline 1. Ambient Condition & 136 & $88 \%$ & 19 & $12 \%$ & 77 \\
\hline 2. Tangibels & 138 & $89 \%$ & 17 & $11 \%$ & 74 \\
\hline Mutu Hasil (Outcome Quality) & 135 & $87 \%$ & 20 & 13 & 76 \\
\hline 1. Waiting Time & 136 & $88 \%$ & 19 & $12 \%$ & 77 \\
\hline 2. Valensi & 141 & $91 \%$ & 14 & $9 \%$ & 77 \\
\hline
\end{tabular}

Keterangan :

B $\quad=$ Baik
SB = Sangat Baik

Gambaran mutu pelayanan kesehatan di unit pelayanan rawat inap RSUD BDH, terdapat 
128 responden $(83 \%)$ menilai mutu pelayanan kesehatan kategori baik dan kategori sangat baik 27 responden (17\%). Tidakterdapat responden menilai mutu pelayanan kesehatan kategori tidak baik dan kurang baik. Nilai ratarata mutu pelayanan kesehatan RSUD BDH adalah 77 , artinya mutu pelayanan kesehtan di unit rawat inap RSUD $\mathrm{BDH}$ yang dinilai berdasarkan prespektif pelanggan berkategorikan sangat baik.
Dimensi mutu interaksi (interaction quality) memiliki nilai mean 77 (kategori sangat baik), mutu lingkungan fisik (physical environment quality) memiliki nilai mean 75 (kategori baik) dan mutu hasil (outcome quality) memiliki nilai mean 76 (kategori sangat baik). Artinya, responden menilai paling tinggi pada dimensi mutu interaksi (interaction quality) dibandingkan dengan dimensi mutu lingkungan fisik (physical environment quality).

\section{Kepuasan Pasien}

Tabel 1.3

Kepuasan Pasien

\begin{tabular}{|l|r|r|r|r|r|}
\hline & \multicolumn{2}{|c|}{ Kategori Nilai } & \multicolumn{2}{c|}{ Frekuensi } & \multicolumn{2}{c|}{$\begin{array}{c}\text { Nilai } \\
\text { Mean }\end{array}$} \\
\cline { 2 - 5 } & P & \% & SP & \multicolumn{1}{c|}{7} \\
\hline Kepuasan Pasien & 54 & $35 \%$ & 101 & $65 \%$ & \\
\hline $\begin{array}{l}\text { Perspektif pemenuhan } \\
\text { kebutuhan dan harapan } \\
\text { pasien }\end{array}$ & 122 & $79 \%$ & 33 & $21 \%$ & \\
\hline $\begin{array}{l}\text { Perspektif penilaian } \\
\text { pelayanan yang sudah } \\
\text { diterima }\end{array}$ & 56 & $36 \%$ & 99 & $64 \%$ & \\
\hline
\end{tabular}

Keterangan:

$$
\begin{array}{ll}
\mathrm{P} & =\text { Puas } \\
\mathrm{SP} & =\text { Sangat Puas }
\end{array}
$$

Gambaran Kepuasan pasien di unit pelayanan rawat inap RSUD BDH, terdapat 54 responden (35\%) menilai kategori puas dan 101 responden (65\%) menilai kategori sangat puas. Tidak terdapat responden yang menilai pada kategori tidak puas dan kurang puas. Rata-rata nilai kepuasan yaitu 79 (kategori sangat puas). Berdasarkan hal tersebut dapat disimpulkan responden menilai kepuasan di unit pelayanan rawat inap RSUD BDH pada kategori sangat puas.

Dari ke dua perspektif tersebut, perspektif penilaian pelayanan yang sudah diterima memiliki nilai mean paling tinggi yaitu 82 dibandingkan perspektif pemenuhan 
STUDI HUBUNGAN ANTARA MUTU PELAYANAN ....(Eka Nurcahyanti)

kebutuhan dan harapan pasien dengan nilai

mean 77. Artinya kedua perspektif kepuasan

tersebut masing-masing berkategorikan sangat

puas, akan tetapi prespektif penilaian pelayanan

yang sudah diterima memiliki nilai mean yang

paling tinggi.

\section{Gambaran Loyalitas Pelanggan}

Tabel 1.4

Gambaran Loyalitas Kepuasan

\begin{tabular}{|c|c|c|c|c|c|c|c|c|c|}
\hline & \multicolumn{8}{|c|}{ Kategori Nilai } & \multirow[t]{2}{*}{ Mean } \\
\hline & $\begin{array}{c}1 \\
\text { TK }\end{array}$ & $\%$ & $\begin{array}{c}2 \\
\text { MK }\end{array}$ & $\%$ & $\begin{array}{c}\mathbf{3} \\
\mathbf{A K}\end{array}$ & $\%$ & $\begin{array}{c}4 \\
\text { PK }\end{array}$ & $\%$ & \\
\hline $\begin{array}{l}\text { Jika anda } \\
\text { membutuhkan } \\
\text { pelayanan } \\
\text { kesehatan lagi, } \\
\text { akankah Anda } \\
\text { datang kembali ke } \\
\text { rumah sakit kami? }\end{array}$ & 0 & $0 \%$ & 2 & $2 \%$ & 120 & $77 \%$ & 33 & $21 \%$ & 3 \\
\hline
\end{tabular}

Pada penelitian ini peneliti tidak

Keterangan:

TK = Tidak Kembali

MK = Mungkin Kembali

AK = Akan Kembali

PK $\quad=$ Pasti Kembali menganalisis mendalam

tentang loyalitas pelanggan. Terdapat $88 \%$ responden memilih skala 3 , artinya responden akan kembali ke RSUD BDH dengan hal tersebut kecenderungan responden loyal terhadap RSUD BDH.

\section{Hubungan Mutu Pelayanan Kesehatan Dengan Kepuasan Pasien}

Tabel 1.5

Hubungan Mutu Pelayanan Kesehatan Dengan Kepuasan Pasien

\begin{tabular}{|l|l|r|}
\hline & Mutu Pelayanan Kesehatan & Kepuasan Pasien \\
\hline Mutu Pelayanan Kesehatan Pearson Correlation & 1 &, $336^{* * 1}$ \\
\hline
\end{tabular}




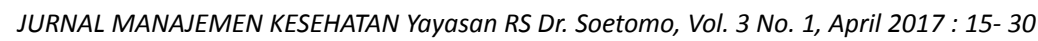

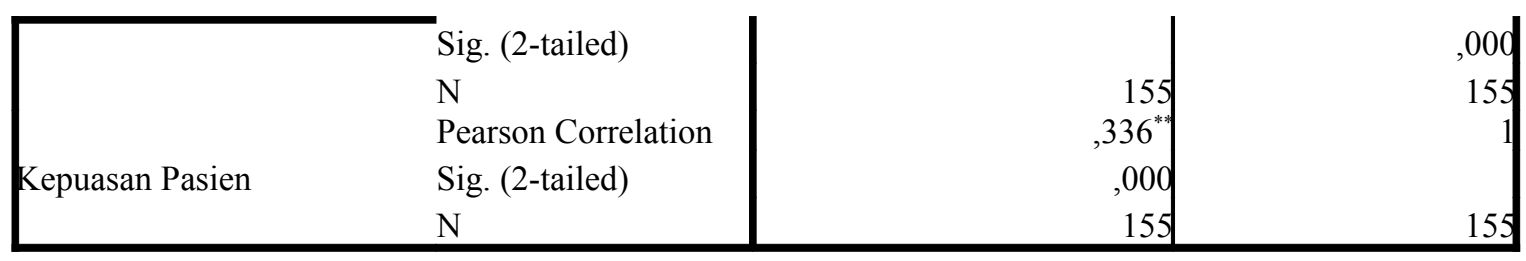

Berdasarkan tabel diatas, diketahui bahwa koefisien kolerasi mutu pelayanan kesehatan dan kepuasan pasien sebesar 0.336, dengan demikian terdapat hubungan yang cukup erat antara mutu pelayanan kesehatan (X) dengan kepuasan pasien (Y).

Nilai koefisien kolerasi positif menunjukkan hubungan lurus, dimana hubungan yang terjadi adalah hubungan positif. Kenaikan suatu variabel akan menyebabkan kenaikan suatu variabel yang lain, sedangkan penurunan suatu variabel akan menyebabkan penurunan variabel yang lain, hal ini berarti semakin cukup mutu pelayanan kesehatan yang diterima maka semakin cukup kepuasan pasien di unit pelayanan rawat inap RSUD BDH. Sebaliknya jika semakin rendah mutu pelayanan kesehatan yang diterima maka semakin rendah pula kepuasan pasien di unit pelayanan rawat inap RSUD BDH Kota Surabaya. Taraf signifikansi pada sig (2-tailed) yaitu 0.000 dimana taraf signifikansi yaitu $p$ hitung $=0.000<0.05$.

\section{Analisis Kanonikal}

Analisis kanonikal dalam penelitian ini yaitu antara pengubah tak bebas (dependent) yang terdiri dari 2 variabel meliputi; mutu pelayanan kesehatan (X) dan kepuasan pasien (Y) dengan peubah bebas (independent) yang terdiri dari 5 variabel, meliputi; X1 dimensi mutu interaksi (interaction Quality), X2 mutu lingkungan fisik (physical environment quality), $\mathrm{X} 3$ mutu hasil (outcome quality), perspektif pemenuhan kebutuhan dan harapan pasien (Y1), serta perspektif penilaian pelayanan yang sudah diterima (Y2). Hasil analisi kanonikal ini terdapat 2 fungsi, yaitu:

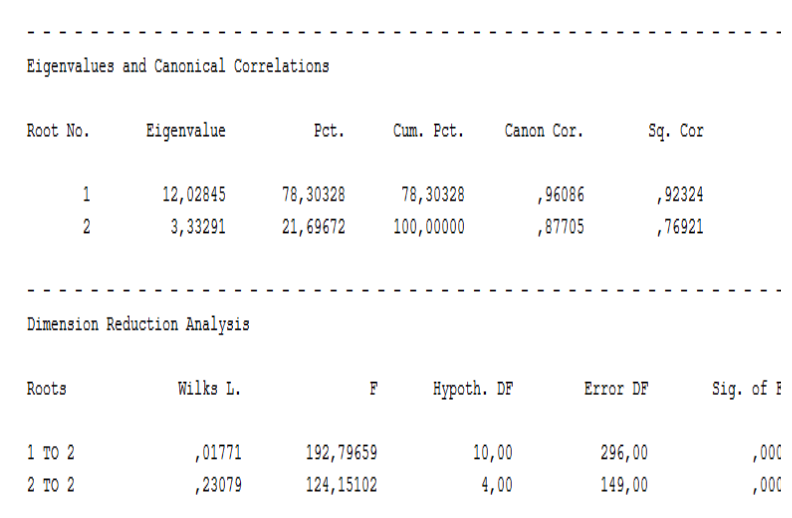

Gambar 1.1

Fungsi kanonikal 1 dan 2

Dua fungsi kanonikal terlihat pada Root No dengan angka kolerasi kanonikal (Canon Cor) untuk fungsi 1 adalah 0.000 dan fungsi 2 adalah 0.000. Kedua fungsi tersebut karena memiliki 
STUDI HUBUNGAN ANTARA MUTU PELAYANAN ....(Eka Nurcahyanti) angka kolerasi dibawah 0.05 maka kedua fungsi tersebut dapat dilakukan analisis selanjutnya.

Setelah diketahui fungsi kanonikal 1 dan 2 signifikan, interprestasi data untuk mengetahui apakah semua variabel independen dalam canonical variate tersebut berhubung erat dengan dependent variate, yang diuukur dengan besaran kolerasi masing-masing independen variabel variatenya. Pengukuran canonical variates dapat dilakukan dengan melihat canonical weight atau canonical loading, sebagai berikut:

\section{a. Bobot Kanonikal (Cannonical Weight)}

Standardized canonical coefficients for DEPENDENT variab Function No.

Variable

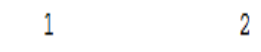

$\begin{array}{lll}X & , 32480 & 1,01075 \\ Y & , 84297 & -, 64537\end{array}$

Standardized canonical coefficients for COVARIATE CAN. VAR.

$\begin{array}{lrr}\text { COVARIATE } & 1 & 2 \\ \text { X1 } & & \\ \text { X2 } & , 21657 & , 74885 \\ \text { X3 } & -, 01657 & , 26041 \\ \text { Y1 } & -, 01195 & , 02910 \\ \text { Y2 } & , 20238 & , 02923 \\ & , 82687 & -, 61218\end{array}$

Gam

bar 1.2

Bobot Kanonikal (Cannonical Weight)

Untuk fungsi 1 pada dependent variabel terdapat satu angka kolerasi, yaitu pada variabel Y yang angka kolerasinya diatas $0.5(0.84297)$.
Sedangkan pada fungsi 2 pada dependent variabel terdapat dua angka kolerasi yang sama tingginya dan diatas 0.05 yaitu 1.01075 dan -0.64537 .

Untuk fungsi 1 pada independent variabel hanya terdapat satu angka kolerasi, yaitu pada variabel Y2 yang angka kolerasinya diatas 0.5 (0.882687). Sedangkan pada fungsi 2 pada independent variabel terdapat dua angka kolerasi yang sama tingginya dan diatas 0.05 yaitu pada variabel X1 0.74885 dan Y2 -0.61218 .

b. Struktur Kanonikal (Canonical Loading)

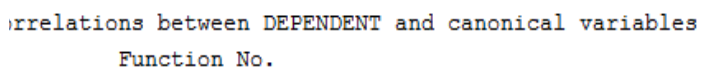
Function No.
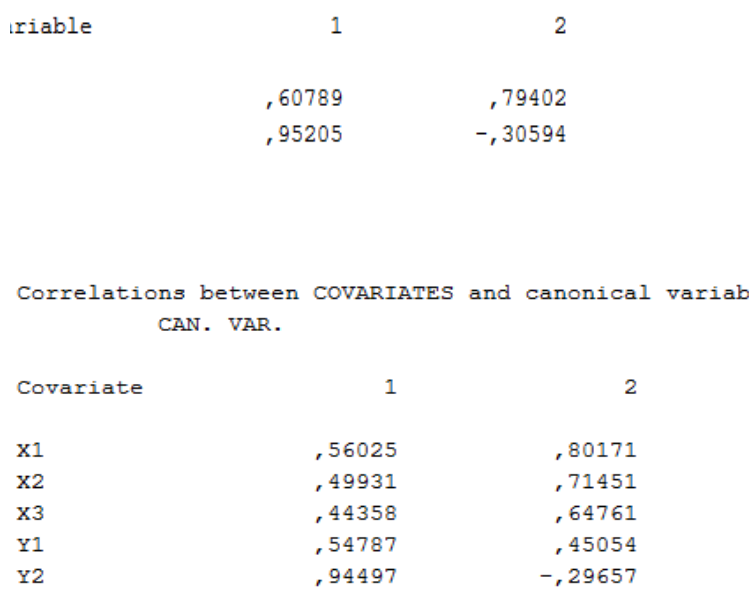

Gambar 1.3

Struktur Kanonikal (Canonical Loading)

Untuk fungsi 1 pada dependent variabel terdapat dua angka kolerasi sama tingginya diatas 0.5 yaitu 0.60789 dan 0.95205. Pada fungsi 2 dependent variabel fungsi terdapat satu angka kolerasi dan diatas 0.05 yaitu X 0.79402 . 
JURNAL MANAJEMEN KESEHATAN Yayasan RS Dr. Soetomo, Vol. 3 No. 1, April 2017 : $15-30$

Untuk fungsi 1 pada independent variabel hanya terdapat tiga angka kolerasi, yaitu pada variabel $\mathrm{X} 1, \mathrm{Y} 2$ dan Y3 yang angka kolerasinya diatas $0.5(0.56025,0.54787$, dan 0.94497). Sedangkan pada fungsi 2 pada independent variabel terdapat tiga angka kolerasi yang sama tingginya dan diatas 0.05 yaitu pada variabel X1 $0.80171, \mathrm{X} 20.71451$ dan X3-0.64761.

Dari hasil canonical weight maupun canonical loading dapat disimpulkan memang terdapat hubungan signifikan antara dependent variate (Mutu Pelayanan Kesehatan dan kepuasan pasien) dengan independent variate(dimensi mutu interakasi, dimensi mutu lingkungan fisik, dimensi mutu hasil, perspektif pemenuhan kebutuhan dan harapan pasien serta perspektif penilaian pelayanan yang sudah diterima). Dari ke 5 variabel independent variate, ke 5 variabel tersebut memiliki keeratan, akan tetapi terdapat satu variabel yang mempunyai kaitan erat paling tinggi dengan Mutu Pelayanan Kesehatan dan Kepuasan Pasien, yaitu X1 dimensi mutu interakasi (interaction quality) dan Y2 (perspektif penilaian pelayanan yang sudah diterima). Tanda positif pada X1 dimensi mutu interakasi (interaction quality), dapat disimpulkan bahwa semakin tinggi dimensi X1 dimensi mutu interakasi (interaction quality) maka semakin tinggi untuk membentuk Mutu Pelayanan Kesehatan dan Kepuasan Pasien di unit pelayanan rawat inap RSUD BDH.

\section{Pembahasan}

\section{Mutu Pelayanan Kesehatan}

Mutu pelayanan kesehatan adalah memenuhi dan melebihi kebutuhan serta harapan pelanggan melalui peningkatan yang berkelanjutan atas seluruh proses (Mary R. Zimmerman dalam Supriyanto, 2011). Mutu pelayanan kesehatan diukur dari 3 dimensi, yaitu dimensi mutu interaksi (interaction Quality), mutu lingkungan fisik (physical environment quality), dan mutu hasil (outcome quality), Brady dan Cornin (2001).Mutu merupakan tingkat baik buruknya sesuatu (Moeliono dkk, 1997).Dengan demikian, jika suatu obyek dalam keadaan baik, maka dapat dikatakan bermutu tinggi, sebaliknya jika obyek tersebut dalam keadaan buruk, maka dapat dikatakan bermutu rendah.

Penelitian ini menunjukan bahwa gambaran mutu pelayanan kesehatan di unit pelayanan rawat inap RSUD BDH, terdapat 128 responden $(83 \%)$ menilai mutu pelayanan kesehatan kategori baik dan kategori sangat baik 27 responden (17\%). Tidakterdapat responden menilai mutu pelayanan kesehatan kategori tidak baik dan kurang baik. Nilai ratarata mutu pelayanan kesehatan RSUD BDH adalah 77 , artinya mutu pelayanan kesehatan di unit rawat inap RSUD BDH yang dinilai berdasarkan prespektif pelanggan berkategorikan sangat baik. 
Hasil penelitian tersebut didukung dengan penelitian di unit rawat inap $\mathrm{B}$ dan $\mathrm{C}$ Rumah Sakit Bhayangkara Tingkat I Raden Said Sukanto, dengan teori yang sama serta hasil yang menyatakan mutu pelayanan kesehatan dinilai kategori sangat baik (Na'ila, 2012).

Mutu pelayanan merupakan evaluasi yang difokuskan pada pengaruh persepsi konsumen terhadap dimensi-dimensi spesifik dari pelayanan, Zeithaml dan Bitner (2000). Mutu pelayanan kesehatan dalam penelitian ini diukur dari beberapa dimensi, yaitu dimensi mutu interaksi (interaction Quality), mutu lingkungan fisik (physical environment quality), dan mutu hasil (outcome quality), Brady dan Cornin (2001).

Dimensi mutu interaksi (interaction quality) memiliki nilai mean 77 (kategori sangat baik), mutu lingkungan fisik (physical environment quality) memiliki nilai mean 75 (kategori baik) dan mutu hasil (outcome quality) memiliki nilai mean 76 (kategori sangat baik). Artinya, responden menilai paling tinggi pada dimensi mutu interaksi (interaction quality) dibandingkan dengan dimensi mutu lingkungan fisik (physical environment quality).

Mutu interaksi (interaction quality) yang terjadi selama proses penyampaian jasa seringkali memberikan pengaruh terbesar pada presepsi mutu jasa, mengingat jasa itu sendiri pada dasarnya memiliki sifat tidak berwujud dan tidak dapat terpisahkan (Bitner et al, dalam Brady dan Cornin 2001). Penelitian di unit pelayanan rawat inap RSUD BDH mendukung teori diatas bahwa dimensi mutu interaksi dinilai paling tinggi sendiri dibandingkan dimensi mutu lingkungan fisik dan dimensi mutu hasil.

Menurut Kallenbach (2008),interaksi merupakan jantung dari pengalaman seorang pelanggan. Jika interaksi yang berlangsung berjalan dengan baik, hal tersebut tidak hanya akan membuat pelanggan puas, melainkan juga senang. Sebaliknya, jika interaksi berlangsung secara buruk, halter sebut akan berujung pada frustasi. Penelitian lain dengan teori yang sama menyatakan bahwa dimensi mutu interaksi (interaction Quality) dirasa paling baik oleh responden di unit rawat inap B dan C Rumah Sakit Bhayangkara Tingkat I Raden Said Sukanto, (Na'ila, 2012).

\section{Kepuasan Pasien}

Menurut Zeithaml dan Bitner (2000:75), kepuasan merupakan penilaian mengenai ciri atau keistimewaan produk atau jasa, atau produk itu sendiri, yang menyediakan tingkat kesenangan konsumen berkaitan dengan pemenuhan kebutuhan konsumsi konsumen. Pada penelitian ini kepuasan pasien diukur menggunakan skala Client Statisfication Quistionare 8. 
Gambaran Kepuasan pasien di unit pelayanan rawat inap RSUD BDH, terdapat 54 responden (35\%) menilai kategori puas dan 101 responden $(65 \%)$ menilai kategori sangat puas. Tidak terdapat responden yang menilai pada kategori tidak puas dan kurang puas. Rata-rata nilai kepuasan yaitu 79 (kategori sangat puas). Berdasarkan hal tersebut dapat disimpulkan responden menilai kepuasan di unit pelayanan rawat inap RSUD BDH pada kategori sangat puas. Didukung dengan hasil survey kepuasan tahun 2015 responden sebagian besar merespon puas $87 \%$. Penelitian ini sejalan dengan penelitian yang dilakukan di Philipina yang menyatakan bahwa responden merasakan kepuasan di pelayanan rawat inap (Matsubara et al, 2013).

\section{Menurut teori Maslow}

kebutuhan manusia tersusun dalam suatu hierarki kebutuhan. Kebutuhan pada tiap hierarki harus dipuaskan termasuk kebutuhan kesehatan, pada hierarki kebutuhan Maslow, kebutuhan kesehatan tergolong dalam physiological needs (Maslow, 1971).

Dalam penelitian ini mendukung teori dari Maslow bahwa gambaran perspektif kepuasan yang terdiri dari 2 prespektif, yaitu: perspektif pemenuhan kebutuhan dan harapan pasien serta perspektif penilaian pelayanan yang sudah diterima. Dari ke dua perspektif tersebut, perspektif penilaian pelayanan yang sudah diterima miliki nilai mean paling tinggi
82 dibandingkan perspektif pemenuhan kebutuhan dan harapan pasien dengan nilai mean 77. Artinya kedua perspektif kepuasan tersebut masing-masing berkategorikan sangat puas, akan tetapi perspektif penilaian pelayanan yang sudah diterima memiliki nilai mean yang paling tinggi. Pendapat lain dari Endang (2012) bahwa kepuasan pasien merupakan evaluasi atau penilaian setelah menerima suatu pelayanan, bahwa pelayanan yang dipilih setidak-tidaknya memenuhi atau melebihi harapan.

\section{Gambaran Loyalitas Pelanggan}

Loyalitas terhadap layanan kesehatan ke rumah sakit mencerminkan komitmen psikologis pengguna atau pasien, maka perilaku menggunakan jasa layanan kesehatan ke rumah sakit itu semata mata menyangkut penggunaan layanan kesehatan ke rumah sakit yang sama secara berulang-ulang (Nugroho, 2008).Penelitian ini mendapatkan hasil bahwadari 1 item pertanyaan yang mengambarkan kecenderungan loyalitas pelangan. Terdapat $88 \%$ responden (77\%) memilih akan kembali ke RSUD BDH. Data hasil tersebut menunjukkan bahwa terdapat kecenderungan loyalitas pelanggan.

Terdapat sebuah studi yang menyatakan bahwa mutu yang dirasakan sebagai mediasi kepuasan pelanggan dan loyalitas di sektor kesehatan. Pendekatan ini menganggap pelayanan yang mutu pelayanan yang dirasakan merupakan mediator hubungan antara kepuasan 
STUDI HUBUNGAN ANTARA MUTU PELAYANAN ....(Eka Nurcahyanti)

pelanggan dan niat pelanggan untuk loyalitas

(Lie dan Alan, 2012). Penelitian ini menunjukkan hasil bahwa mutu pelayanan kesehatan yang bermutu mampu membuat pelanggan menjadikan kecenderungan loyal kepada RSUD BDH.

\section{Hubungan Mutu Pelayanan Kesehatan Dengan Kepuasan Pasien}

Kepuasan pasien berkaitan dengan mutu pelayanan dengan jasa pelayanan yang diberikan. Hal ini menjadikan sangat penting bagi rumah sakit untuk meningkatkan mutu pelayanan yang membedakan dari pesaing dan meningkatkan persepsi maupun citra positif dalam masyarakat. Peningkatan mutu pelayanan akan dapat mempertinggi kepercayaan pelanggan dalam masyarakat (Yamit, 2001).

Berdasarkan hasil perhitungan kolerasi tersebut hipotesis yang diajukan yaitu ada hubungan antara mutu pelayanan kesehatan dengan kepuasan pasien di unit pelayanan rawat inap. Taraf signifikansi pada sig (2-tailed) yaitu 0.000 dimana taraf signifikansi yaitu $\mathrm{p}$ hitung $=$ $0.000<0.05$. Angka koefisien kolerasi yaitu 0.336, hal tersebut menunjukkan bahwa kolerasi antar mutu pelayanan kesehatan dengan kepuasan pasien terdapat hubungan yang cukup. Penelitain tersebut sejalan dengan penelitian Zaniarti (2011) menyatakan bahwa terdapat hubungan yang signifikan antara mutu pelayanan kesehatan dengan kepuasan pasien di unit pelayanan rawat inap RSUD Salatiga.

\section{Analisi Kanonikal}

Mutu interkasi yang terjadi selama proses penyampaian jasa seringkali memberikan pengaruh terbesar pada presepsi mutu jasa, mengingat jasa itu sendiri pada dasarnya memiliki sifat tidak berwujud dan tidak dapat terpisahkan (Bitner et al, dalam Brady dan Cornin 2001). Penelitian ini dari hasil analisis canonical weight maupun canonical loading dapat disimpulkan memang terdapat hubungan signifikan anatar dependent variate mutu pelayanan kesehatan dan kepuasan pasien dengan independent variate yaituX1 dimensi mutu interaksi (interaction quality), X2 dimensi mutu lingkungan fisik (physical environment quality), $\mathrm{X} 3$ dimensi mutu hasil (outcome quality), Y1 perspektif pemenuhan kebutuhan dan harapan pasien, dan Y2 perspektif penilaian pelayanan yang sudah diterima.

Dari hasil canonical weight maupun canonical loading dapat disimpulkan memang terdapat hubungan signifikan anatar dependent variate dengan independnet variate. Dari ke 5 variabel independent variate, ke 5 variabel tersebut memiliki keeratan, akan tetapi terdapat satu variabel yang mempunyai kaitan erat paling tinggi dengan mutu pelayanan kesehatan dan Y kepuasan pasien, yaitu X1 dimensi mutu interkasi (interaction quality). Tanda positif pada X1 dimensi mutu interaksi (interaction quality), dapat disimpulkan bahwa semakin 
JURNAL MANAJEMEN KESEHATAN Yayasan RS Dr. Soetomo, Vol. 3 No. 1, April 2017 : 15- 30

tinggi dimensi X1 dimensi mutu interaksi (interaction quality) maka semakin tinggi untuk membentuk mutu pelayanan kesehatan dan kepuasan pasien di unit pelayanan rawat inap RSUD BDH.

\section{KESIMPULAN DAN SARAN}

\section{Kesimpulan}

1. Uji hipotesis hubungan mutu pelayanan kesehatan dengan kepuasan pasien di unit pelayanan rawat inap RSUD $\mathrm{BDH}$ diterima. Terdapat hubungan yang signifikan antara mutu pelayanan kesehatan dan kepuasan pasien ( $\mathrm{p}$ hitung = $0.000<0.05)$.

2. Mutu pelayanan kesehatan sebagian besar dirasakan pada kategori sangat baik.

3. Dari ketiga dimensi, dimensi mutu interaksi (Interaction Quality) dirasakan pada kategori sangat baik dan memiliki nilai rata-rata paling tinggi.

4. Faktordari masing-masing dimensi mutu meliputi; Sikap dan Prilaku Perawat, Keahlian, Ambient Condition, Waiting Time dan Valensi rata-rata dinilai pada kategori sangat baik oleh responden.

5. Kepuasan pasien dinilai pada kategori sangat puas.
6. Terdapat kecenderungan loyalitas pelanggan.

\section{Saran}

Berdasarkan hasil penelitian, analisis data dan kesimpulan diatas, maka peneliti mengajukan saran-saran kepada RSUD BDH Kota Surabaya sebagai berikut:

1. Bagi Rumah Sakit Umum Daerah Bahkti Dharma Hasada

a. Bagi RSUD BDH hendaknya dapat mempertahankan mutu pelayanan kesehatan bagi pasien, khusunya pasien rawat inap. Serta memahami dan mengetahui pelayanan kesehatan yang terbaik demi mewujudkan pelayanan kesehatan yang bermutu sehingga dapat meningkatkan kepuasan pasien serta menjadikan pasien loyal.

b. Bagi RSUD BDH harus mempertahankan dimensi mutu interkasi (interaction quality) yang sudah dicapai pada kategori sangat baik.

c. Sikap dan prilaku perawat serta keahlian harus dipertahankan dengan baik.

d. Sebaiknya rumah sakit meningkatkan upaya pemenuhan fasilitas fisik (tangibels).

2. Bagi Peneliti Lain 
STUDI HUBUNGAN ANTARA MUTU PELAYANAN ....(Eka Nurcahyanti)

Bagi peneliti yang berminat mengadakan penelitian yang sama lebih lanjut, sebaiknya peneliti memilih metode yang lebih cepat dalam pengumpulan data, yaitu dengan sekala sebagai alat ukur tetapi sebaiknya menggunakan metode wawancara mendalam untuk mendapatkan hasil yang lebih akurat. Selain itu hendaknya merencanakan proses penelitian karena menghadapi atau menggunakan subjek penelitian dari kelompok pasien harus penuh kesabaran dan pengertian akan kondisi pasien, sehingga diharapkan pasien sebagai subyek penelitian dapat memberikan

\section{DAFTAR PUSTAKA}

Arikunto, S. 2010. Prosedur Penelitian: Suatu Pendekatan Praktik (Edisi Revisi). Jakarta: Rineka Cipta.

Attkison C. 1983. Client Statisfication Quistonare 8.

Boedijoewono, Nugroho. 2001. Pengantar Statistik Ekonomi dan Perusahaan. Yogyakarta: UPD AMP YKPN.

Brady, M.K., \& Cronin J.J.J, 2001. Some New Thoughts on Conceptualizing Perceived Service Quality: A Hierarchical Approach. Journal of Marketing, Vol. 65, No. 3, pp. 34-49.

Budi, Wahyono. 2012. Sistem Manajemen Mutu (Quality Management System) ISO 9001:2008, diakses tanggal 8 Mei 2016 dari,

http://www.pendidikanekonomi.com/2012 /07/sistemmanajemen-mutu-quality.html

Chahal, H., and Kumari, N, 2010. Development of Multidimensional Scale For Healthcare Service Quality (HCSQ) in Indian
Context. Journal of Indian Business Research Vol.2, No.4, pp.230-255.

Dwi, Zaniarti. 2011. Hubungan Kualitas Pelayanan Kesehatan Dengan Kepuasan Pasien Rawat Inap Jamkesda Di RSUD Salatgia. Skripsi. Universitas Negeri Semarang: Fakultas Pasikologi.

Gerson, Richard. F. 2004.Mengukur Kepuasan Pelanggan, PPM, Jakarta.

Kallenbach,Jan.2008. TheExperienceofInteractionQuality.Helsi nki UniversityofTechnology. 12Maret2012.http://www.cs.uta.fi/ uxemotion/ submissions/Kallenbach.pdf

Kementerian Kesehatan RI., 2011. Standart Akreditasi Rumah Sakit Edisi Ke-1. Jakarta: Kemenkes RI.

Kotler, Philip. 2005. Prinsip-prinsip Pemasaran. Jakarta: Erlangga.

Lei, Ping \& Jolibert, Alain, 2012. A ThreeModel Comparison Of The Relationship Between Quality, Satisfaction And Loyalty: An Empirical Study of The Chinese Healthcare System. Journal of BMC Health Services Research Vol.436, No.12, pp. 1472-6963.

Maslow, A. 1971. The Third Force: The Psychology Of Abraham Maslow. Washitong: Washinting Square Press.

Matsubaar et al. 2013. Reliability tests and validation tests of the client satisfaction questionnaire (CSQ-8) as an index of satisfaction with childbirth-related care among Filipino women. Journal of BIO Med.

Moeliono, Anton M. 1997. Kamus Besar Bahasa Indonesia. Jakarta: Balai Pustaka.

Nanik. 2012. Faktor-faktor Yang Berhubungan Dengan Pemanfaatan Pelayanan Kesehatan Di Puskesmas Sumber Rejo Kota Balikpapan. Skripsi. Depok. Peminatan Kebidanan 
JURNAL MANAJEMEN KESEHATAN Yayasan RS Dr. Soetomo, Vol. 3 No. 1, April 2017 : 15- 30

Nugroho, Wisnu. 2008. loyalitas-pasienterhadap-rumah-sakit.html

Na'ila, Rahmita, S.N., 2012. Studi Kualitas Jasa Instalasi Rawat Inap B Dan C Rumah Sakit Bhayangkara Tingkat 1 Raden Said Sukanto. Skripsi. Jakarta. Universitas Indonesia.

Parasuraman, A., Zeithmal, Valarie A., dan Berry, Leonard L. 1985. Delivering Quality Service: Balancing Customer Preception adn Expextations. New York: The Free Press.

Pohan, Imbalo, S. 2006. Jaminan Mutu Layanan Kesehatan : Dasar-Dasar
Pengertian Dan Penerapan, Jakarta : EGC.

Supriyanto. 2011. Mutu Pelayanan Kesehatan. Yogyakarta: Andi.

Undang-Undang Republik Indonesia No.44, 2009. Rumah Sakit. Jakarta: Republik Indonesia.

Yamit. 2001. Manajemen Kualitas Produk dan Jasa. Yogyakarta: Ekognisa.

Zeithaml, Valarie A and Mary Jo Bitner. 2000. Service Marketing. Singapore: Mc GrawHill Companies Inc.: 3-287. 